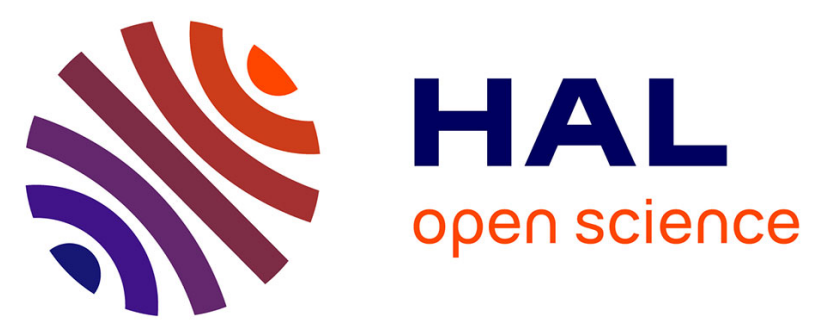

\title{
Ferric Substance Formed in Water Circulating in Boilers and Steam Piping, and an Apparatus for Magnetic Treating it
}

\author{
S. Ishibashi, T. Sato, M. Yokoyama, K. Haneda, Y. Kato
}

\section{- To cite this version:}

S. Ishibashi, T. Sato, M. Yokoyama, K. Haneda, Y. Kato. Ferric Substance Formed in Water Circulating in Boilers and Steam Piping, and an Apparatus for Magnetic Treating it. Journal de Physique IV Proceedings, 1997, 07 (C1), pp.C1-531-C1-532. 10.1051/jp4:19971217 • jpa-00254889

\section{HAL Id: jpa-00254889 https://hal.science/jpa-00254889}

Submitted on 1 Jan 1997

HAL is a multi-disciplinary open access archive for the deposit and dissemination of scientific research documents, whether they are published or not. The documents may come from teaching and research institutions in France or abroad, or from public or private research centers.
L'archive ouverte pluridisciplinaire HAL, est destinée au dépôt et à la diffusion de documents scientifiques de niveau recherche, publiés ou non, émanant des établissements d'enseignement et de recherche français ou étrangers, des laboratoires publics ou privés. 


\title{
Ferric Substance Formed in Water Circulating in Boilers and Steam Piping, and an Apparatus for Magnetic Treating it
}

\author{
S. Ishibashi, T. Sato, M. Yokoyama*, K. Haneda** and Y. Kato***
}

Faculty of Engineering, Tokyo Engineering University, 1404-1 Katakura, Hachioji, Tokyo 192, Japan

* Faculty of Science and Technology, Keio University, 3-14-1 Hiyoshi, Kohoku-ku, Yokohama, Kanagawa

223, Japan

** School of Science and Technology, Ishinomaki Senshu University, 1 Minamisakai Sinmito, Ishinomaki, Miyagi 986, Japan

***NTT advanced Technology, 3-1 Morinosato Wakamiya, Atsugi, Kanagawa 243-01, Japan

\begin{abstract}
Substances in side the boilers and pipes become attached as scale or precipitate, and these badly effect the thermal efficiency of the steam We made a detailed investigation, particularly on the ferric substances which are present in boilers for heating buildings, generating steam at $100^{\circ} \mathrm{C}$ and boilers which supply $180^{\circ} \mathrm{C}$ steam to multistory buildings In the case ofheating buildings, $20 \%$ of these substances are made up of $\mathrm{Fe}_{3} \mathrm{O}_{4}$. The average particle size of $\mathrm{Fe}_{3} \mathrm{O}_{4}$ is $17-27$ $\mathrm{nm}$, and the saturation magnetization $\sigma_{\mathrm{s}}$ is $65 \sim 85 \mathrm{emu} / \mathrm{g}$, by correcting the content of calcite and non-magnetic surface layer. The substances in boilers which supply multistory buildings contain $\sim 98 \%$ of $\mathrm{Fe}_{3} \mathrm{O}_{4}$ and $\alpha-\mathrm{Fe}_{3} \mathrm{O}_{4}$, whose average particle size is 105 and $160 \mathrm{~nm}$ respectively. The $\sigma_{s}$ of $\mathrm{Fe}_{3} \mathrm{O}_{4}$ was $79-92 \mathrm{emu} / \mathrm{g}$, if we correct the content of the nonmagnetic layer, and this value is almost the same as for the bulk material. In our present research we tried to attach a bypass in the pipe and set a magnet from outside, and the substances can be removed from the system while the boiler in still in operation.
\end{abstract}

\section{Introduction}

Boilers are widely used to generate steam in various field, such as buildings and thermal power plants. Substances adhere to boilers and their piping facility as scale or precipitate as sludge. These substances disturb the flow of steam and badly effect the thermal efficiency of the steam. Researches on the composition of these substances have been reported [1], however, the detailed data on ferric substance in composition of such scale and sludge are not well known yet . We made an investigation, particularly on the ferric substances which are present in boiler for heating buildings, generating steam at $100^{\circ} \mathrm{C}$ and boilers which supply $180^{\circ} \mathrm{C}$ steam to multistory buildings [2]. In our present research, we made a detailed study on the ferric substance formed in these boilers, and tried to attach a bypass in the pipe and set a magnet from outside in order to remove ferromagnetic ferric substance, $\mathrm{Fe}_{3} \mathrm{O}_{4}$, in the boiler.

\section{Experimental procedure and results}

Arrangement of the boiler, heat exchanger and pipings is shown in Fig. 1. The substances formed in the boiler are yellowish, and are magnetically separated by agitating them in ethanol. The substances taken out from the boiler is called [A], the magnetically-attracted substances is called [B], and non-magnetically- attracted one are called [C]. These substances were determined by Fluorescent X-ray spectrographic analysis (XFA). These materials were determinedby X-ray diffraction (XRD) and the average crystalline size $D_{311}$ was evaluated from the width a half maximum of X-ray diffraction line (311) of [B], using Scherre's formula. The particle morphology was observed by transmission electron microscopy (TEM). The element analysis was madeby Energy Dispersive X-ray Spectroscopy (EDX). Magnetization measurements in a magnetic field of up to $15 \mathrm{kOe}$ at $300 \mathrm{~K}$ were performed by using a vibrating sample magnetometer(VSM). A trial experiment was conducted with a magnetic collective unit by constructing a magnetically-controlling apparatus.

In case of the boiler for heating, water supply is made with city water with a $\mathrm{pH}$ of 7.4, which increased to a pH of 10.5 after 6 months during the operation. The XFA data of $[\mathrm{A}],[\mathrm{B}]$, and $[\mathrm{C}]$ reveals that $\mathrm{CaCO}_{3}$ is contained most, which might supposedly be caused by the use of the city water. Then, $\mathrm{Fe}_{3} \mathrm{O}_{4}, \mathrm{SiO}_{2}$, and $\mathrm{MgCO}_{3}$ are the order. $\mathrm{Fe}_{3} \mathrm{O}_{4}$ is contained more than $20 \%$. On the other hand, the boiler for supplying high-temperature steam is in operation under a pH of 11.5 and the deionized water is used for water supply. Thus, almost none of substances such as $\mathrm{CaCO}_{3}, \mathrm{MgCO}_{3}$, are contained, where as ferric oxides are contained $98 \%$. Fig. 2 shows $\mathrm{XRD}$ patterns of $[\mathrm{A}],[\mathrm{B}]$, and $[\mathrm{C}]$ formed in the boilers. The heat-generation temperature is $100^{\circ} \mathrm{C}$ in case of heating and $\mathrm{CaCO}_{3}$ (calcite), spinel structure substance, and $\mathrm{SiO}_{2}$ can be seen with $[\mathrm{A}]$, but the intensity of $\mathrm{CaCO}_{3}$ is the greatest. The intensity of XRD by the spinel structure is the greatest with [B], and almost all of EDX data shows the peaks by Fe. With [C], 
almost all consist of $\mathrm{CaCO}_{3}$. This coincides with the $\mathrm{XFA}$ data described above. The steam-generation temperature is $180^{\circ} \mathrm{C}$ in case of high-temperature steam supply, and $\mathrm{Fe}_{3} \mathrm{O}_{4}$ and $\alpha-\mathrm{Fe}_{2} \mathrm{O}_{3}$ are seen with $[\mathrm{A}]$ by XRD. The intensity of $\mathrm{Fe}_{3} \mathrm{O}_{4}$ is the greatest with $[B]$, and almost all consist of $\alpha-\mathrm{Fe}_{2} \mathrm{O}_{3}$ with [C]. The lattice constants of $\mathrm{Fe}_{3} \mathrm{O}_{4}$ and $\alpha-\mathrm{Fe}_{2} \mathrm{O}_{3}$ coincide with that of the bulk materials. The average particle size of $\mathrm{Fe}_{3} \mathrm{O}_{4}$ is $17-27 \mathrm{~nm}$ with respect to the boiler for heating, and is $105 \mathrm{~nm}$ with respect to the one for high-temperature steam supply. In accordance with TEM observation, either the particle is gramular. On the other hand, $\alpha-\mathrm{Fe}_{2} \mathrm{O}_{3}$ is $160 \mathrm{~nm}$ and is the hexagonal particle. The $\sigma_{s}$ with $[\mathrm{B}]$ of the boilers for heating and high-temperature steam supply, remains 35-51 and $79 \mathrm{emu} / \mathrm{g}$, respectively. The contents of the ferromagnetic fineparticles are great enough to be $67-77$ and 92 emu/g, respectively, in consideration of the existence of non-magnetic substances, $\mathrm{CaCO}_{3}$, and non-magnetic surface layer [3]. Thus it is revealed that the magnetization of the ferromagnetic fine particles is considerably close to $92 \mathrm{emu} / \mathrm{g}$ of the bulk Fe $\mathrm{O}_{4}$.

An example of the apparatus is shown in Fig. 3. With the plant, collective is made by allowing the substances to be attracted to fall with a bypass attached on part of the pipings and with a magnet equipped on the outer side of the bypass. Furthermore, an example was given by changing the configuration of the magnet to allow the magnetic field to be biased, to be inversely-biased, and to be in parallel. In this investigation, the flow rate and concentration of the aqueous solution were compelled to follow the condition as close as possible to the duration of the operation of the boiler. Higher raise of the collective ratio was noted for the biased and inversely-biased magnetic fields compared with the parallel magnetic field. Additionally, from the TEM observation of the collective and non-collective substances, the result of the composition analysis of the small area with a diameter of $\sim 20 \mathrm{~nm}$ by EDX is shown in Fig. 4. Judging concurrently from the above-mentioned result and both the results of the fluorescent X-ray spectrographic analysis and XRD in Fig. 2, it can be said that (1) in Fig. 4 are the particles corresponding to $\mathrm{CaCO}_{3}$, whereas (2) are the particles corresponding to $\mathrm{Fe}_{3} \mathrm{O}_{4}$.

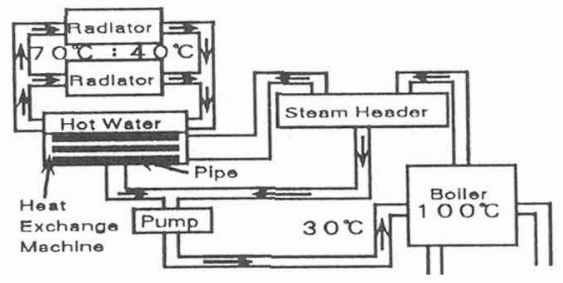

Figure 1: Arrangement of the boiler and piping facility.

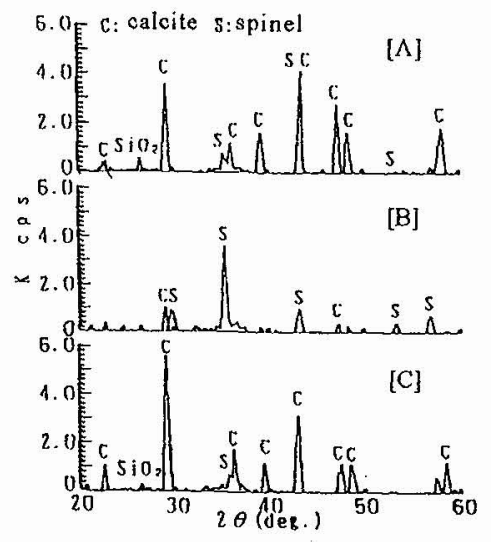

a): Boiler for heating buildings.

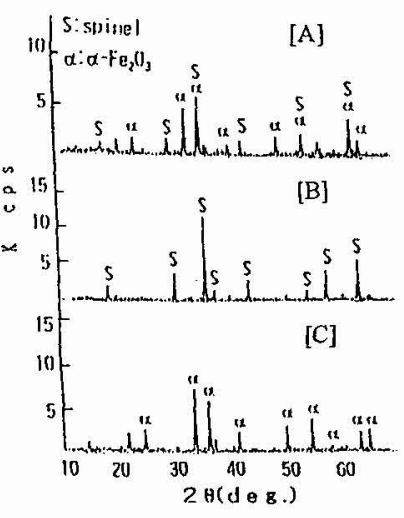

b): Boiler for supplying high-temperature steam.

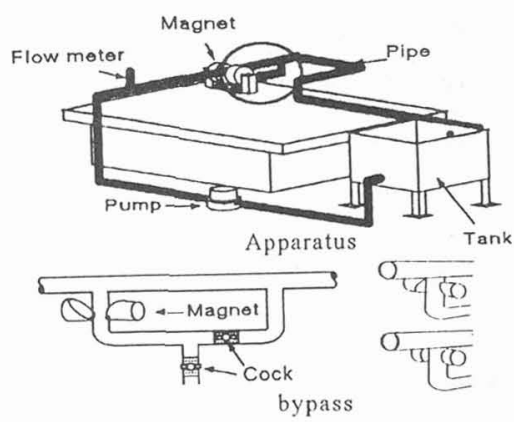

Figure 3: Apparatus and bypass in a collective experiment.

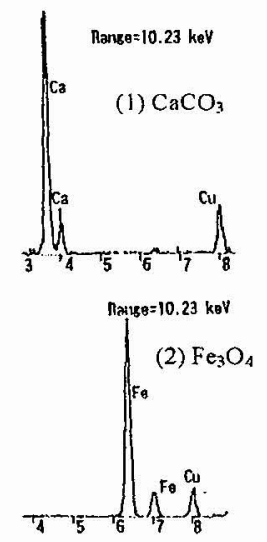

Figure 2: X-ray diffraction patterns of substances formed in boiler.

\section{References}

Figure 4: Element analysis using EDX.

[1] Hand book of Therm. Pow. Plant, Central. Res.,(1985)

[2] S. Ishibashi, T. Sato, K. Haneda, and Y. Kato, J, Magn. Soc. Jpn., 20, (1996) 509.

[3] T. Sato, T. Iijima, M. Seki, and N. Inagaki, J. Magn. Magn. Mat. 65, (1987) 252. 